\title{
UM WALKIE-TALKIE NA ENCRUZILHADA DAS ÁGUAS: TRADUZIR E CANTAR A POESIA XAMÂNICA MARUBO
}

\author{
Guilherme Gontijo Flores $\underline{1}$ \\ 1Universidade Federal do Paraná, Curitiba, Paraná, Brasil
}

\begin{abstract}
Resumo: O presente ensaio ${ }^{1}$ buscar relatar a experiência de traduzir dois cantos xamânicos Marubo para performance vocal a partir do trabalho de Pedro Cesarino, tanto na etnografia como na tradução poética. Para tanto, o texto se desdobra em um relato de percurso e em algumas ponderações teóricas sobre os problemas de traduzir uma poética xamânica ameríndia em português, com seus dilemas éticos e poéticos.
\end{abstract}

Palavras-chave: Xamanismo; Tradução Poética; Cantos Ameríndios

\section{A WALKIE-TALKIE WHERE WATERS MEET: TRANSLATING AND SINGING MARUBO SHAMANIC POETRY}

\begin{abstract}
This essay seeks to report the experience of translating two Marubo shamanic chants for vocal performance starting from the work of Pedro Cesarino, both in ethnography and poetic translation. To this end, the text unfolds into an account of the course and into some theoretical considerations about the problems of translating an Amerindian shamanic poetics into Portuguese, with its ethical and poetic dilemmas.
\end{abstract}

Keywords: Shamanism; Poetic Translation; Amerindian chants

${ }^{1}$ Agradeço imensamente as leituras e comentários de Alexandre Nodari, Álvaro Faleiros, Luciane Alves e sobretudo a confiança e gentileza de Pedro Cesarino. 
yove mawa chinãyai

chinãyai shokosho

sabiás-além pensantes

pensando juntos vivem

(formula de canto iniki marubo)

The WORST thing about written prose is that there is no SILENCE

in it.

(Dennis Tedlock)

\section{1}

Em oito de novembro de 2016, quando andava por calçadas da cidade velha de Belém, estourei pela segunda vez o dedão do pé direito, resultado de uma unha encravada depois de um acidente futebolesco que não vem ao caso, já que se dera quase um ano antes. Esta é a primeira lembrança que tenho da $V$ Ciella - Congresso Internacional de Estudos Linguístico e Literários na Amazônia, que começava no dia seguinte. O resultado é que passei os próximos dias sentindo dor intensa, manco, de sandálias, nessa capital incrivelmente quente e úmida do Norte. Quando lembro especificamente de conhecer Pedro Cesarino, antropólogo, professor e escritor que eu já lera no seu Oniska - poética do xamanismo na Amazônia, não posso mais dissociar a alegria mental da dor no dedo: estão as duas entrelaçadas no que trago hoje. Afinidade imediata, marcamos uma cerveja para o fim do dia, talvez o seguinte, até que lá, entre copos, lhe propus uma ideia que vinha me atravessando pelo menos desde 2014, quando engrenei minhas pesquisas e práticas sobre poética e performance vocal de línguas variadas ${ }^{2}$. Eu queria saber se Pedro toparia algum tipo de parceria com os cantos marubo que ele já traduzira, para tentar algum tipo de performance

${ }^{2}$ Compreendo aqui, como Henri Meschonnic em toda sua obra, que todo texto tem uma oralidade, uma potência de voz que se cumpre até nas sintaxes mais complexas, como as de um Proust. A vocalidade, ou a poética vocal, aqui se diferencia por marcar que uma determinada obra foi feita para a voz e realizada na voz, e não apenas guarda um traço geral.

Cad. Trad., Florianópolis, v. 39, n $^{0}$ esp., p. 171-226, set-dez, 2019 
vocal traduzida em língua portuguesa que seguisse os mesmos padrões rítmicos e melódicos dos cantos marubo. Pedro, ele próprio tradutor, diante da demanda, fez a coisa certa: hesitou. Estava em jogo aqui não um processo simples de reperformance e encenação de um poema ocidental, feito no jogo dos sistemas literários e/ou musicais; pelo contrário, um canto xamânico marubo tem função cosmopoética muito diferente, e a própria ideia de iteração em contextos diversos pode ferir não só os marubo mas nossa própria relação com a diversidade do que se engloba no vago termo do poético (perguntas ficaram sem resposta definitiva, tais como "um canto xamânico de cura é um poema?", “onde termina a feitura do poema?”, "qual é a função da função poética se o poema não quer buscar chamar atenção para a própria linguagem?”). Pedro hesitou e, hesitante com ele, não insisti demais. Tomamos outros copos.

Durante outro evento, agora em Rouen, na França, ouvi Guillaume Boussard, tradutor de Lucrécio ao francês em padrões rítmicos hexamétricos e também impressionante performer de poemas em latim e francês, dizer que, se alguém quisesse ficar fora de si, não precisaria necessariamente de drogas: bastaria recitar com vigor uns cinquenta hexâmetros gregos ou latinos, que a ação corporal garantiria um movimento rumo ao transe. Em nenhum instante duvidei que ele pensava nas técnicas arcaicas do êxtase, que o livro clássico de Mircea Eliade relaciona diretamente ao xamanismo. Boussard sabe muito bem que cantar é agir sobre o outro $^{3}$, mas sem dúvida é agir sobre si mesmo; mais precisamente, o canto como êxtase coletivo só acontece quando ele próprio se

\footnotetext{
${ }^{3}$ A construção do corpo como uma espécie de artefato fabricável, tema recorrente de alguns estudos, ganha uma primeira forma notável no artigo de Seeger, Da Matta;Viveiros de Castro (1979). O canto, como as intervenções de grafismos e marcas corporais, dentre outras práticas, assim fabrica o corpo, tanto por fora quanto por dentro.
}

Cad. Trad., Florianópolis, v. 39, n $^{0}$ esp., p. 171-226, set-dez, 2019 
faz êxtase no cantor, tenha ele uma formação de origem espontâ-

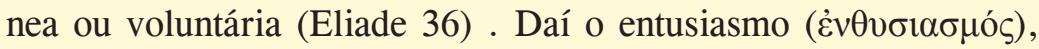
essa presença do divino dentro do corpo ( $\varepsilon v \theta \varepsilon \circ \varsigma)$, que marca todo poeta no mundo grego arcaico, seja na forma da Musa, seja na forma do dom irracional; fato que faz com que Jacyntho Lins Brandão proponha a tradução "estar endeusado" (20). Daí também o vaká, ou duplo, dos Marubo, que canta seu canto no corpo-carcaça de um pajé-romeya que funciona como uma espécie de rádio (“o pajé é um rádio" já escrevera Viveiros de Castro em 1986), porém singularmente um rádio-ouvinte, um rádio-comunicador, ou walkie-talkie $^{4}$, uma associação já recorrente na Amazônia entre a função do xamã e a do rádio.

Por outro lado, há também a necessidade de uma saída de si, e não apenas a incorporação do outro. A percepção de que há um vínculo entre iniciação xamânica e a experiência de morte atravessa o relato de Davi Kopenawa \& Bruce Albert, e o movimento de saída fica claro quando, por exemplo, lemos:

\begin{abstract}
É nossa imagem que os xapiri [espíritos] levam desse modo, para consertá-la. Primeiro extraem de dentro de nosso corpo, para depositá-la em seus espelhos celestes. Enquanto isso nossa pele, muito enfraquecida, queda-se estendida na praça de nossa casa, na floresta. Então os espíritos extraviam nosso pensamento e nossa língua, para nos ensinar a sua. Depois nos dão a conhecer o desenho da floresta, para que possamos protegê-la. (142)
\end{abstract}

Isso se dá também num ritual entre humanos, como vemos em seguida:

\footnotetext{
${ }^{4}$ Essa ideia do rádio, desdobrada em rádio-comunicador, surgiu de uma conversa com Alexandre Nodari, que então chegou à imagem do walkie-talkie.
} 
Quando o pai de minha esposa me fez virar outro, tudo ocorreu como acabo de descrever. Com a yãkoana, ele primeiro tirou de mim todo o vigor. O seu espírito, que chamamos Yãkoanari, foi comendo minha carne aos poucos. Fiquei tão fraco que dava dó! Os xapiri então lavaram do meu peito todo cheiro ácido e salgado. Fizeram-me perder toda a força e fizeram-me voltar a ser um bebê. Depois de algum tempo, meu sogro chamou outros espíritos para virem se instalar comigo. (ibid 143)

Como atenta Carolina Villada Castro, já pensando em tradução "desde a iniciação xamânica, tornar-se pajé implica uma experiência quase mortal, pois implica um sair de si, isto é, uma passagem à exterioridade como limiar" (107), ao mesmo tempo em que pode instalar espíritos consigo. Ao falar da iniciação do camaiurá $\mathrm{Sa}$ paim, Orlando Villas Bôas atenta: "O pajé nunca é dono de si" (62), porque a escolha de aceitar a vocação e aprender a técnica é a resposta a um chamado irrecusável dos mamaé (espíritos). Assim, lugar do transe e do sonho é também uma passagem de morte, tópica recorrente em todo o livro de Eliade. Nesse sentido, sendo um incorporar que é também um sair de si, o êxtase contém um aprendizado duplo: por um lado, demanda ele próprio um domínio de suas técnicas, fazendo do sonho um tipo de saber a ser manipulado com maior ou menor perícia (Kopenawa; Albert 132-156, 462-3); por outro, o resultado desse domínio da técnica é a porta para o aprendizado tradutório que é a própria vivência das alteridades cruzadas $^{5}$ : o xamã canta um canto que não é seu e, ao ouvi-lo, aprende

${ }^{5}$ Cf. Irving Goldman sobre a formação do pajé kubeo (2004: 334): “Shamanistic knowledge is largely technical, as other Vaupés scholars have already noted, requiring the memorization of chants, a familiarity with traditions, an understanding of ritual usage, and an accurate grasp of the properties of drugs and pertinent flora and fauna, indeed of the nature of the biosphere as a whole. Students as well as payés are evaluated (I suspect they were at one time ranked) by a public perception of their formal knowledge. This type of evaluation is not 
o saber que vem dos espíritos da mata, escuta o que seu corpo alterado canta e nesse curto-circuito age sobre si e sobre os outros.

Foram as imagens dos sabiás yõrixiama, dos japins ayokora e dos pássaros sitipari si, todos donos dos cantos, que arrancaram minha língua. Pegaram-na para refazê-la, para torná-la bela e capaz de proferir palavras sábias. Lavaramna, lixaram-na e alisaram-na, para poder impregná-la com suas melodias. Os espíritos das cigarras a cobriram com penugem branca e desenhos de urucum. Os espíritos do zangão remoremo moxi a lamberam para livrá-la aos poucos de suas palavras de fantasma. Por fim, os espíritos sabiá e japim puseram nela as de seus magníficos cantos. Deramlhe a vibração de seu chamado: "Arerererere!". Tornaramna outra, luminosa e brilhante como se emitisse raios. Foi assim que os xapiri prepararam minha língua. Fizeram dela uma língua leve e afinada. Tornaram-na flexível e ágil. Transformaram-na numa língua de árvore de cantos, uma verdadeira língua de espírito. Foi então que eu pude enfim

the same as judging the efficacy of healing, for Cubeo are not simple-minded in their expectation of healing results."

Por outro lado, na cultura mbya guarani, segundo Elizabeth Pissolato (2007: 346), “ o que todos os opita'i va'e enfatizam é que nõ se aprende com outro xamã o ofício. mas é Nhanderu que 'mandou' ou 'deu' isto a ele(a). O mesmo afirmariam os Apapokúva: “alguém não pode tornar-se pajé, a não ser por inspiração; um pajé nunca pode ser treinado para tal, mesmo que isso se dê por iniciativa das maiores autoridades no assunto", diz Nimuendaju ([1914] 1987, p. 75)[...].

[...] Mas Cadogan considera ainda que este momento resultaria de um período preparatório que pode durar anos, em que o "neófito", então, buscaria meios de receber a inspiração entoando cantos, participando das sessões de reza, sendo hospitaleiro, caridoso, tendo "amor ao próximo".

Formalmente, não existe uma preparação de 'neófitos' entre os Mbya com que vivi”. A conclusão de Pissolato é (ibid.: 348): “Minha impressão é que, por um lado, só é xamã quem recebe dos deuses capacidades para agir como um especialista na cura e /ou reza, seus poderes e conhecimento não podendo ser transmitidos por outros xamãs. Por outro lado, só permanece xamã quem persiste na prática de disponibilizar seus poderes de cura e reza ao longo de um período, e tanto mais, se nesta atividade torna-se reconhecido e mantém-se com o passar do tempo". 
imitar suas vozes e responder a suas palavras com cantos direitos e claros. (ibid. 154-5)

Os xapiri fazem uma intervenção sobre o corpo de Davi Kopenawa, purificam e transformam sua língua: sua escuta é a condição de uma nova fala, de um novo canto, que é o canto dos ancestrais. O xamanismo não é então "um sistema de saber ou de fatos sabidos, mas antes uma técnica de saber. Não é um discurso constituído, mas o modo de constituir um", diz Graham Townsley (452) sobre os Yaminawa, porém num modelo que pode ser ampliado ${ }^{6}$. O sonho e o transe, com sua vizinha à morte, não são a mera perda da razão, mas um princípio comunicativo, mais especificamente cosmopoético, em que fazer é não só agir sobre o outro (curar, ou modular), mas aprender, traduzir.

\section{3}

Total translation é a expressão - talvez infeliz em seu suposto senso de totalidade - que Jerome Rothenberg deu a seu experi-

${ }^{6} \mathrm{Cf}$. pouco adiante, (454): “This mimicking, through which humans momentarily gain control over the non-human by becoming like it, thus creating a shared space of communication, is precisely the goal of the shaman's song." "My songs are paths" said a shaman, "Some take me a short way — some take me a long way - I make them straight and I walk down them - I look about me as I go - not a thing escapes my notice - I call - but I stay on the path."

The image of the hunter on his path sums up perfectly the types of knowledge shamans use, and their context. Firstly, the vast and detailed empirical knowledge; the understanding, achieved by constant practice, of the things of the forest, their forms, colours, sounds, habits, the places they frequent and the foods they eat. Secondly, the knowledge of signs; the ways to interpret the traces left by things that rarely reveal themselves directly (the interpretation of dreams and visions is a fascinating and vast topic which I will not treat here, but it is worth mentioning that beyond the direct communications shamans claim from yoshi, they also interpret all aspects of their visions - movements, colours, formal distortions - as indirect, coded communications). Finally, shamanism is also knowledge of the paths, the myths and, above all, the songs." 
mento de tradução da Cantos-Cavalo (Horse Songs) originalmente realizados por Frank Mitchell (1881-1967), um cantor de origem navajo, sediado em Chinle, Arizona. No artigo homônimo ("Tradução total" em português), Rothenberg explica passo a passo como tomou conhecimento das obras de Mitchell em 1968, portanto um ano depois da morte do cantor, como se preparou para a tradução e, mais especificamente, como percebeu que a poética navajo era vocal num sentido bastante radical: em sua performance, ela distorcia a linguagem chegando a tocar um ponto do que não pode ser propriamente traduzido na semântica apenas:

\begin{abstract}
A grande questão, da qual eu estava imediatamente consciente [...], era como lidar com aqueles elementos nas obras originais que não eram literalmente traduzíveis. Como no caso da maioria da poesia índia [sic], a voz carregava muitos sons que não eram, no sentido exato, 'palavras'. Estes sons tendiam a desaparecer ou a ser atenuados na tradução, como se realmente não estivessem lá. Mas eles estavam lá \& eram pelo menos tão importantes quanto as próprias palavras. (2006:38)
\end{abstract}

O resultado dessa percepção é que, por traduzir poesia de olho no papel, a tradição tradutória havia despojado os cantos de um aspecto significativo (em todos os aspectos de "significativo") que transcendia a mera semântica lexical. O exemplo pelos cantos de Mitchell é perfeito:

A linha de abertura, na transcrição de McAllester, é a seguinte:

dzo-wowode sileye shi, dza-na desileye shiyi, dzanadi sileye shiya'e.

mas o mesmo segmento, considerado "na fala", aparece assim: 


\section{dzaadi silá shi dzaadi silá shi dzaadi silá shi}

que é traduzido como 'aqui isto é lá (\&) meu' e repetido três vezes. Esta é a linha a ser cantada se o significado for tudo que você tem a considerar. Em outras palavras, traduza apenas pelo significado \& você alcança a repetição de três partes de uma única afirmação invariável; mas no idioma navajo a cada vez que a frase é apresentada há um acentuado afastamento da forma falada: portanto ocorrem três resultados sonoros distintos, e não um em triplicado! (ibid.:39-40)

O que Rothenberg percebe aqui é que uma poética vocal realiza os recursos de uma poética da voz que: por um lado, foge à nossa convenção clichê de que o oral é coloquial, uma vez que mostra que a linguagem da poética da voz é tudo, menos equivalência plena da fala ${ }^{7}$; por outro, usa uma série de recursos sonoros que não cabem nos léxicos tradicionais da língua, nem assumem uma semântica clara e traduzível, são muitas vezes chamados de "palavras de canto" e já foram entendidos em sua força mágica num estudo clássico de Bronislaw Malinowski (1935) acerca dos trobriandeses. Este segundo aspecto por vezes aparece transcrito, porém não traduzido, na maior parte das traduções de poesia nahuatl, por exemplo, ou na dificuldade de codificar com que seriam as "palavras de música" para os Kĩsêdjê (cf. Seeger 48, 96-7) ${ }^{8}$. Assim, para Rothenberg, o

${ }^{7}$ Um bom exemplo conciso dessa questão na poética marubo é dado por Pedro Cesarino numa nota: (2013: 37, n. 37), que assim conclui: “Tais exemplos , aos quais outros diversos poderiam ser somados, mostram que ao menos os primeiros trabalhos de tradução devem ser feitos em parceria com um falante nativo não apenas bilíngue, mas também versado no conhecimento da língua ritual ou poética das artes verbais." É contando com esse primeiro trabalho de Cesarino junto aos romeya marubo que posso me arriscar a outra empreitada.

8 Guilherme Orlandini Heurich, por exemplo, apesar de estudar as poéticas araweté, opta por não transcrever os refrões, assim descritos: "Alguns refrões poderiam ser traduzidos, mas outros não, e optei por exclui-los completamente da apresentação dos cantos na tese [...] Reconhecer essa importância, no entanto, 
que está em jogo não é a recodificação de língua a língua, nem o assentamento de um inglês transparente em melodia navajo, mas "replicar poema-a-poema na tentativa de formular uma tradução 'total' - não só das palavras, mas de todos os sons conectados ao poema, incluindo, por fim, a própria música" (ibid.: 40). O que também pode ser entendido como empenho de apresentar análogos vocais, mas não necessariamente representar o tema como descrição (ibid.: 50). Chamar isso de "total" é, certamente, uma confiança excessiva de Rothenberg, porque este desconsidera da performance o seu local, contexto e função social ou, como usei antes, cosmopoética. Nesse sentido, o dilema ético de Cesarino, traduzido em problema puramente poético, fica esvaziado de sentido. Rothenberg quer contorcer o inglês diante da poética navajo, e aqui o ato político da poética é de invasão da língua opressora por aspectos poéticos da língua dominada. Como observa Alexandre Nodari:

\begin{abstract}
A magistralidade formal do gesto de Rothenberg é traduzir não a partir da posição do enunciador nativo, e nem mesmo do auditório/ouvinte nativo, mas sim do ouvinte estrangeiro. Ele não omite a própria posição de estrangeiro, o próprio lugar de escuta, antes, busca traduzir essa estrangeiridade para a própria língua: ele transporta esse lugar de escuta estrangeiro para o inglês, sua língua nativa. Não se trata de reproduzir o lugar de fala, ou mesmo de escuta, do outro, mas de transpor um lugar de escuta, o seu próprio lugar de escuta numa língua estrangeira, para dentro da sua própria língua nativa. A língua nativa se torna estrangeira, e o espaço do poema (a tradução/performance do canto) se torna, assim, um lugar $d a$ escuta, que demanda que seus
\end{abstract}

não significa necessariamente ter de grafar os cantos com os refrões, principalmente porque o objetivo deste trabalho não é replicar em papel uma arte verbal ameríndia. Escutar um canto oñi ñã me'e e, principalmente, ver um xamã araweté cantar esses cantos é uma experiência que, do ponto de vista do papel, já está perdida desde o início." (205: 155-56). Mais adiante, ele lembra: “Alguns refrões são compreensíveis para os Araweté, outros não, pois são sílabas curtas que nada significam" (ibid.: 174). 
leitores ocupem um lugar (estrangeiro) de escuta. (online, grifos do autor)

O resultado impressionante de seu trabalho está gravado nas dezessete Horse Songs, de $1977^{9}$. E ainda assim a demanda ética não termina: há um tensionamento que não podemos deixar de lado.

\section{4}

No começo de 2019 tomei conhecimento do primeiro disco do pianista e tenor Jeremy Dutcher, Wolastoqiyik Lintuwakonawa, algo que pode ser traduzido mais ou menos como "canções wolastoqiyik", por ser um disco inteiramente gravado na língua dos Wolastoqiyik (ou Wlastakwewiyik, ou Maliseet), que habitam para do vale do rio Saint John, nas fronteiras New Brunswick e Quebec no Canadá, bem como partes do Maine nos Estados Unidos, de cujo grupo Dutcher faz parte. A delicadeza e força do disco estão em duas escolhas muito marcantes. Em primeiro lugar, Dutcher dialoga com gravações feitas em tubos de cera, datadas do começo do século passado, onde ouvimos parte dos cantos tradicionais em vozes de antepassados mortos; Dutcher, em vez de apenas mostrar a gravação de modo arqueológico, ou de calá-la para fazer sua própria performance atualizada, opta por cantar em diálogo com seus mortos; nesse movimento, sua voz forte de tenor se tensiona com a fragilidade da gravação e das vozes arcaicas. Em segundo lugar, Dutcher reorganiza os cantos com arranjos para piano e outros instrumentos que flertam com a música pop e erudita ao mesmo tempo, sem cair no desejo de manutenção estática do passado, mas apostando no diálogo entre modos de canto e música. O resultado

${ }_{9}$ O áudio completo pode ser ouvido no YouTube: https://www.youtube.com/ watch?v=qTmsctQz_WE\&t=283s; e também em dois vídeos de Rothenberg, para a primeira canção: https://www.youtube.com/watch?v=AwOMvl5c2iU. E para a segunda: https://www.youtube. $\operatorname{com} /$ watch? $\mathrm{v}=1 \mathrm{Wk} 1$ XoFYDe4\&t $=138 \mathrm{~s}$. Alguns áudios se encontram no álbum Origins and meanings, de 1968.

Cad. Trad., Florianópolis, v. 39, nº esp., p. 171-226, set-dez, 2019 
é um canto wolastoqiyik colado ao passado, porém atravessado por um presente variado da música contemporânea, que assim se torna acessível a um ouvinte leigo e ao mesmo tempo se recusa a fazer uma tradução linguística. Ouve-se um saber wolastoqiyik, mas nem mesmo em seu site consigo descobrir o sentido de cada letra, elas permanecem fechadas, como as "palavras de música", como que fazendo o canto para além da semântica.

Talvez o caso mais marcante seja a primeira canção do álbum, "Mehcinut", constituída por apenas uma palavra que é repetida inúmeras vezes e que reconheço sonoramente como Yanigwedo. Segundo Dutcher em entrevistas, a palavra não existe no léxico wolastoqiyik, o que o faz pensar que seria apenas uma vocalização sem sentido, ou algum termo tão arcaico na história da língua que já não é nem mais reconhecido, nem reconhecível por aproximação etimológica; ou então termo tomado de outra família e ainda não identificado. Seja como for, aqui temos um momento singular: Dutcher canta em wolastoqiyik uma canção que nem ele mesmo reconhece semanticamente; seu título "Mehcinut" é derivado do discurso que o cantor original na gravação em cera faz após seu canto, e que ainda segundo Dutcher versa sobre a morte. Neste momento, diante de um saber dessa canção sem semântica clara, me perguntei: como se traduz um canto que ao mesmo tempo, não está em nenhuma língua específica, se ele ainda guarda uma relação clara de sentido e, talvez, rito, neste caso com a morte e sua circularidade no mundo?

Não é aqui o momento de explicar procedimentos de deriva, mas decidi traduzir a canção sem alterar a palavra Yanigwedo: ela era o fascínio musical, tanto na voz anônima e arcaica quanto em seu diálogo com Dutcher e instrumentos. Caberia apenas um percurso de não-tradução tradutória: o enxerto sobre o discurso anônimo como uma torção do sentido. Para tanto, o grupo Pecora Loca a performa cantando a mesma melodia em tempos e variações completamente livres para cada um dos integrantes (já a performei de duas a seis pessoas), sem qualquer uníssono, enquanto um dos membros lê o texto abaixo (em geral, eu leio o poema, mas ele 
também já foi performado por Iván García López, Ricardo Pozzo e André Capilé em momentos singulares):

Vem morte amável e calmante, Ondula mundo afora, chegando, chegando serena, De dia, de noite, a todos, a cada, Cedo ou tarde, morte delicada.

Louvado seja o universo insondável, Por vida e gozo, por objetos e conhecimento estranhos, E por amor, doce amor - mas louvem! louvem! louvem! Pelos braços de enlace firme da morte fresca-envolvente.

Negra mãe pairando sempre perto com pés leves, Ninguém cantou por ti um canto pleno de acolhida?

Então canto por ti, glorifico-te acima de tudo, Trago-te uma canção pra quando tiveres de fato de vir, que venhas inexorável.

Achega-te forte libertadora, Quando assim for, quando os tiveres levado, eu canto alegremente os mortos,

Perdidos no amoroso oceano fluido que é teu, Amados no fluxo de tua bênção Ó morte.

De mim pra ti gratas serenatas,

Danças pra ti eu proponho saudando-te, enfeites e festas prati,

E as visões da paisagem aberta e do céu extenso, condizentes,

E a vida e os campos e a noite imensa e pensativa.

A noite em silêncio sob tantos astros.

A margem do oceano e a rouca onda sussurrante cuja voz eu conheço,

E a alma voltada pra ti Ó morte vasta e bem velada, E o corpo agradecido aninhado junto a ti. 
Sobre copas de árvores te flutuo a canção,

Sobre ondas que sobem e descem, sobre a miríade de campos e amplos prados,

Sobre as cidades condensadas todas e cais e vias fervilhantes, Alegre, alegre flutuo pra ti este cântico Ó morte.

Trata-se de um excerto do trecho 14 do poema "When Lilacs Last By the Dooryard Bloom'd", de Walt Whitman, em minha tradução intitulada "Na Última Florada de Lilases na Varanda". É, na verdade, uma espécie de tradução xamânica: no poema, Whitman, como numa pajelança fúnebre, diz escutar o canto do pássaro castanho-gris e o traduz ao inglês, é essa tradução whitmaniana que traduzo ao português. É ela que ponho em relação dupla com o sem sentido de Yanigwedo e o discurso anônimo da morte em "Mehcinut". Curioso é saber que, quando André Capilé ouviu o canto pela primeira vez em português, traduziu em seu ouvido $\mathrm{Ya}$ nigwedo como "E amigo é dor".

Não poderia estar mais certo.

\section{5}

Pedro Cesarino me respondeu que não teria condições de responder pelos Marubo sobre a tradução de um canto para outros contextos; isso eu nem poderia questionar. Mas depois de pensar, considerou que havia um corpus pequeno que poderia receber essa "tradução total" a partir da sua própria tradução: eram os dois cantos de Iskõ Tae, seu vaká (duplo e irmão mais velho do próprio Pedro, também pensável como "um dos aspectos da pessoa", 2011: 414), cantados pelo xamã romeya Armando Cherõpapa Txano (também conhecido como (ou Armando Mariano Marubo) num rito de cura. A história é no mínimo singular: ao fim, Pedro me permitiu traduzir o próprio vaká, duplo dele, essa figura que permanece dentro e fora do mundo marubo, como ele próprio. Entra 
aqui uma questão importante sobre escrita no mundo marubo, que Cesarino assim resume:

\begin{abstract}
Nesta tradição oral não há nenhum traço de presença da escrita (alfabética ou não), a não ser o criado pela intervenção do presente livro, que não se origina de uma intenção política local como do poema maia-quiché. Como foi dito, a compilação não que se apresenta surge de uma iniciativa minha, acolhida de bom grado pelas aldeias em que vivi durante meu trabalho de campo. Logo no início, quando o projeto era explicado e aceito pelos cantadores, xamãs e moradores locais, ele passou a se tornar de interesse dos mesmos, a ponto de desejarem que documentações e transcrições fossem feitas nas outras aldeias em que eu não trabalhei. $O$ objeto (e projeto) 'livro', que era um mistério para os cantadores locais, foi aos poucos assimilado através da criação de uma categoria local, a de documento (apropriação do termo português: documento): algo que se deve mostrar aos chefes dos brancos para que se garanta a integridade das terras, para que o saber seja reconhecido, para que os Marubo sejam enfim tratados com o devido respeito. (Cesarino 18, grifos meus)
\end{abstract}

Assim como Cesarino precisou apresentar um projeto próprio para os cantos (transcrição, tradução, livro) e contar com o aceite dos marubo, que tradicionalmente apenas os cantavam sem registro escrito, para ao fim emergir como chance de reconhecimento dos marubo perante os brancos, também eu desloco seu projeto em outro, contando com a possível aprovação, mas acreditando na hipótese - singela e ínfima que seja - que ela possa ter de, por um lado, ligar pensamento via performance e, por outro, ampliar um pouco devido respeito aos marubo. Neste caso, a tradução, ou mais especificamente a tradução que reperforma vocalmente, precisa funcionar, usando termos de Álvaro Faleiros, como "um canto-agente que se desdobra, como rios que se cruzam”, como 
"espaços de cruzamentos de mundos" (152), ideia tirada do artigo seminal de Manuela Carneiro da Cunha (2009). Assim como o pensamento vai se desdobrando polifônico, pergunto-me até que ponto a tradução, sendo ou não xamânica em seu gesto, suporta os desdobramentos e entrecruzamentos, sem perder a necessária ligação do pensamento, dos que pensando juntos vivem entre si e com a imensa série de espíritos que povoam o mundo.

6

Eu nunca tinha lido precisamente o epílogo de Oniska, por motivo que não consigo resgatar: por que não ler o que encerra? O que me desligou ali o pensamento desse jeito? Logo a vivência com o duplo, a conclusão de um percurso que não se fecha inteiro. As últimas palavras de Cesarino ali são mais que certeiras:

Descubro aí nesse iniki que, além de ter um duplo que me ajuda a pensar, também os tios foram responsáveis pela minha capacidade de entender os cantos. Eles sopraram ou enviaram tal saber para mim através dos inaladores de rapé. O rewe não é apenas um soul catcher, mas também um transmissor de conhecimento, de chinã, que é também palavra utilizada para designar os duplos. Ora, conhecer significa aqui personificar. Sangama, o índio piro sobre o qual escreve Peter Gow em An Amazonian Myth ans its History, via por trás das letras uma mulher-espírito de boca vermelha, brilhante com seu batom. Por conta disso, ele conseguia decifrar os livros dos brancos e impressionar os seus parentes analfabetos. Por uma inversão simétrica, o antropólogo que vos escreve parece ter aprendido esses cantos por intermédio de seus tios-espírito e, mais adiante, de seu próprio duplo irmão. Aprender é tornar-se apto para repetir, traduzir ou reproduzir os saberes de outrem; colocar-se em relação com uma coletividade e um campo de parentesco; 'ligar pensamento', enfim. (402) 
De algum modo, aqui encontro a justificativa mais séria para a tradução poética: como um modo intenso de aprendizado, como preparação para uma repetição modalizada ou diferenciada, ou mesmo diferida, a tradução é a preparação para reproduzir saberes de outrem, mesmo que venham num complexo telefone sem fio de livros e conversas. Num texto pouco posterior, que acompanha suas traduções de cosmologia marubo, Cesarino explica um pouco mais a questão, quando comenta "Pajé Flor de Tabaco", cantado por Armando Mariano Marubo:

\begin{abstract}
É bastante fértil a expressão que, no canto, designa a relação entre dois xamãs: chinã ãntinãnãi, algo como 'trocar pensamento', permanecer em sintonia ou em conexão com alguém. Como dissemos, esta é a expressão empregada para descrever, por exemplo, uma relação que se estabelece entre este antropólogo e os seus interlocutores ao longo do trabalho de tradução. É esse um dos objetivos principais xamanismo, ligar pensamento, estabelecer uma comunidade de reflexão entre pessoas 'faladoras', 'loquazes' ou 'cantadoras', vanaya. E a analogia com o processo de tradução não é gratuita, uma vez que o xamanismo marubo pode ser compreendido como uma rede de dialogicidade tecida ao longo de um cosmos babélico, multilíngue e multi-humano. Os pajés estão sempre às voltas com os males desta terra, caracterizados pela feitiçaria, pela doença e morte, mas também pela desagregação, dispersão e esquecimento. (2013: 193-4)
\end{abstract}

Nesse aspecto, um laboratório de tradução, o convívio entre alguém que tem maior convívio e saber do mundo e língua dos Marubo, é a condição para a produção do outro saber da tradução que canta e recanta o canto original. Cesarino, nesse aspecto, aqui o ocupa um lugar de tio que fala comigo, entre e-mails e mensagens de WhatsApp; a voz de Tekãpapa atravessada pelo canto de Iskõ Tae, é um outro tio que jamais compreendo plenamente, e, no entanto, me atravessa. 
7

De certo modo, Rothenberg se retrata no mesmo artigo na seguinte nota:

Por trás de tudo isto há também um motivo escondido: não apenas tornar claro o mundo do original, mas fazê-lo com alguma distância da própria canção: para refletir a canção sem o 'perigo' de apresentar alguma parte dela (a melodia, por exemplo) exatamente como conhecida: consequentemente tê-la ao não tê-la, por respeito ao senso de discrição e de localização que é tão importante àqueles a quem as canções são sagradas \& vivas. Assim as mudanças que resultam da tradução são, neste caso, não só inevitáveis, mas desejadas, ou, como um seneca me disse 'Não gostaríamos que as canções fossem parar tão longe de nós; não, as canções ficariam muito sós.' (2004: 50)

O que daqui se depreende é que, na relação de uma poética vocal e sagrada, na tradução de cantos sagrados, a noção de traduttore traditore se inverte: é precisamente a disposição a uma traição do senso e da forma que, por outro lado, preserva o canto de seu extravio perigoso; distorcê-lo na outra língua e na outra voz é também um modo fiel de preservação, porque é reconhecimento do abismo que constitui o passo tradutório: lance de tempo e espaço. Essa posição de respeito é a procura de uma via própria de execução da nova performance.

\section{8}

No epílogo de Oniska, Cesarino conta como pode pela primeira vez ouvir um canto de seu vaká Iskõ Tae, que então já tinha aprendido parte das artes verbais necessárias para produzir um iniki. Ele consegue ouvir e gravar alguns cantos, porém depois de tudo, 
quando tenta ouvir as gravações, percebe que a pilha tinha acabado e que nada fora gravado. Terei aqui de fazer uma citação longa do livro, para que surja melhor o contexto dos dois cantos de Iskõ Tae que eu mesmo pude ouvir por gentileza de Pedro.

“Na noite seguinte, explico [o problema da gravação]. Cherõpapa a falha no gravador e pergunto se ele pode chamar de novo o meu irmão. O romeya me explica que os duplos e espíritos costumam ficar bravos quando chamados sem razão em noites seguidas: na ausência de um doente, não haveria como garantir a visita de tal pessoa, já que outras estariam por vir para cá durante a noite. 'É como você', diz um pajé-rezador ali presente, 'que não vem sempre aqui e que precisa de um propósito para aparecer'. Espero mais uma noite. Dessa vez ele volta acompanhado de seu tio (koka), Varĩ Pena, que é o seu protetor, a pessoa responsável por ele (a toĩya yora). 'Por que vocês me chamaram?', diz novamente o vaká, que, descubro, se chama Iskõ Tae (eu mesmo me chamo Isko Mayãpa e somos todos do povo japó, iskonawavo). 'Chamamos para imitar de novo as suas falas', justifica-se Tekãpapa. O vaká parece um pouco contrariado. Mas canta:

\author{
ẽ chinã kenerao \\ ene kenemataki \\ yove kenemataki \\ $\tilde{e}$ anõ oĩa \\ aivo kenese \\ chinã revõ veyamash \\ kenekia rakánõ \\ ẽ anõ vanaa \\ é chinã kene \\ é chinã kenenõ \\ teki vakĩ ikirao \\ eri rivi yonã
}




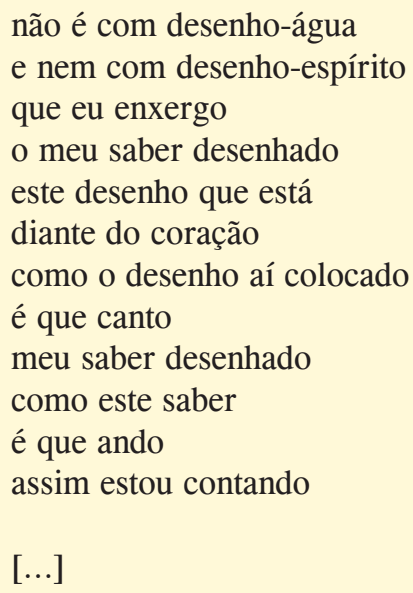

Neste canto, ele mostra que se utiliza de outra tecnologia de conhecimento, distinta daquela dos yora e seus parentes espalhados pelo sociocosmos, que possuem desenhos-espírito marcados no peito (de seus duplos). O saber de Iskõ Tae, meu irmão, é também marcado por desenhos, mas diferentes. Em seguida Vari Shawe, o Espírito-Tartaruga-Sol que ali também chegou, faz algumas perguntas sobre mim [...]. 'Agora não dá mais para pegar de volta. Mas vamos tentar. O seu corpo é como o daquele que está falando com vocês [refere-se a mim]. Vamos tentar de novo aqui. SE você não conseguir, não vai chorar [brinca comigo e todos riem]'. E segue conversando, enquanto, sem sucesso, repetia aquela operação já descrita:

Não é ruim o lugar em que ele [Varĩ Pena, o tio] mora, é parecido com o dele, com o dele [com o meu, Pedro]. Estou falando daquela pessoa responsável por ele [por meu duplo]. A pessoa responsável por ele é seu tio, é Varĩ Pena, o seu tio que o pegou há tempos. Ele tem cinto, tem faca. Sua camiseta é verdeazul, verdeazul mas cheia de bolinhas. Ele tem chapéu, tem faca. Também tem sapato. Ele vive assim mesmo 'Acho que parece comigo' [o locutor imita uma suposta fala minha]. Quando dizem "vamos pelo caminho 
do rio', eles vão de outra maneira. Quando querem chegar rápido, fazem assim. Chegam por cima do rio chegam por cima do rio. O dono disso, o dono disso não sou eu. $\mathrm{O}$ dono dele não sou eu [Jaboti-Sol], o dono é outro. Eu sou outro, sou outro. O dono (ivo) é Varĩ Pena, é dele (awẽ ná). Quando chegam, eu venho na frente [da canoa de metal]. Mas não faz barulho de motor, vai soando a melodia de rio, são os ventos-rio, os ventos-rio (ene werasĩ). Então eles têm a sua melodia (mane), a coisa de se deslocar não vai fazendo barulho mesmo, é o vento deles, o vento deles através dos quais eles vêm para cá. Não é devagarzinho, é muito rápido, assustador. Pode até jogar [as pessoas] para fora. Mas para o seu dono não tem perigo." (2011: 397-8)

Depois o Espírito Jaboti-Sol canta o seu iniki; em seguida Varĩ Pena canta outro iniki, na mesma melodia (ibid.: 398-9). É singular esse aspecto na gravação: há uma continuidade de forma e também de performance entre os cantos, que também vão se formando com técnicas formulaicas (similares àquelas famosas de Parry \& Lord acerca da poesia homérica), de modo que há uma mistura de voz a cada espírito ou espectro que assuma a fala.

Mas segue Cesarino.

“Todos os cantos aí presentificam a referência-água: o coletivo de espíritos que acompanham meu duplo vem daquela região desde sempre identificada aos estrangeiros, o grande rio noa que fica a jusante. Não por acaso, dizem que sou noa mawa, sabiá do rio grande, gente faladora. Depois de um curto intervalo de tempo, é a vez de meu próprio duplo, Iskõ Tae, cantar o seu iniki: 
2. Vari Waka wera we reto iniai ene koĩ wichnãrao retorave iniai

ene mai keneno ene mavã shokoa machit awainiai ene vai teasho ene txoa rakáa watxo itãe kaniaivõ machit ati awema ikivomã ikitõ ene txoa rakáa machit awainiai áve ea paríki ene matso wetsãnõ matis awá voshká veõini otivo matsi awá voshkapá teki ina iki

tsoa mané vitima ea veso ayavõ noa mawa vana vanakavi yosisho eri rivi yonã

ẽ yora shakárao nea mai shavayash matõ vana tanai awẽ aki amainõ é rome kokavõ yove rewe kenenõ vana mekiarao ato vana yosii mãta ẽ akai 
ẽ chinã kenerao

ẽ anõ oĩya

aivo kenese

chinã revõ veyamash

yove kene vetsãi

yove kenematai

vari waka wera

we retó iniai

ene koũ wichnara

reto rave iniai

awesa oĩi

oĩra ikia

nori rivi oĩno

ẽ rome kokavo

ato anõ tsekaa

tseka yosisho

eri rivi anõsho

iki anõ ána

ẽ rome kokavo

ari rivi vanai

vento do Rio-Sol

contra o vento vou

névoa da nuvem-rio

contra a névoa vou

nos rachos da terra-rio

os espinhos-rio fincados

pulando mesmo vou

a gigante raia-rio

que fecha o caminho-rio*

esta pessoa jovem

não consegue mais pular

é o que dizem

mas a gigante raia-rio 
pulando mesmo vou

assim sempre fui

noutra colina do rio

cabeça de anta-frio / blocos de argila

há tempos colocaram

as cabeças de anta-frio

/ os blocos de argila

vão rolando e rolando / / vão subindo e subindo*

os que cantos entregaram***

foram meus protetores

e fala de sabiá do rio

sua fala aprendi

assim estou contando

meu corpo-carcaça

aí neste mundo

a sua língua entendeu****

e enquanto isso

meus tios-espírito

com caniços desenhados / com vozes desenhadas

a fala arrumaram

e a ele ensinaram $* * * * *$

mas eu sempre soube

pelo pensar desenhado

que uso para ver

este desenho traçado

diante do meu coração

feito desenho-espírito

desenho-espírito não é

vento do rio-sol

pelo vento vou

névoa da nuvem-rio

contra a névoa vou

o que será

que ali encontrarei?

juntos vamos ver 
meus tios-espírito
a extrair aprenderam
para que eu mesmo
assim também faça
foi o que falaram
os tios-espírito

Iskõ Tae emenda seu canto em um shõki a ser empregado para curar um doente que ali estava presente. Os kẽchĩtxo escutam o canto ensinado pelo duplo e, em seguida, passam à rede onde está deitado o paciente para curá-lo. Convidam-me - parece-lhes evidente que eu agora também possa cantar - , mas eu declino a oferta sincera e prefiro ficar quieto. Meu irmão talvez tenha essa habilidade, que, para mim, é ainda um desafio. De fato, Iskõ Tae é mesmo quase-espírito, não é como o meu corpo-carcaça, uma pessoa mortal. Mesmo assim, mesmo sendo mais sabido do que eu (seu irmão mais novo), meu duplo não está ainda totalmente formado, vive soba tutela de seu dono ou tio, com quem aprende. (ibid.: 399-401)

São esses os dois cantos de Iskõ Tae na voz Armando Cherõpapa Txano, gravados, transcritos e traduzidos por Pedro Cesarino, que eu poderia traduzir. Cesarino não faz nenhuma nota à primeira peça, mas aqui cito as notas à segunda:

* Trata-se da mãe do rio, a mãe da raia, explicava Veña$\mathrm{pa}^{10}$. É uma raia muito grande que não aparece nunca, fica

${ }^{10}$ Como diálogo ao comentário de Cesarino, eis um trecho de Eduardo Viveiros de Castro sobre o assunto, de modo mais geral: “a noção de espíritos 'donos' dos animais ('Mães da caça', 'Mestres dos queixadas' etc.) é, como se sabe, de enorme difusão no continente. Esses espíritos-mestres, invariavelmente dotados de

Cad. Trad., Florianópolis, v. 39, n $^{0}$ esp., p. 171-226, set-dez, 2019 
nas profundezas dos rios. O canto mostra que o vaká pode, se quiser, viajar pelo fundo do rio, isto é, pela terra-rio, que é repleta de perigos e, por isso, frequentemente comparada ao Caminho-Morte. Trata-se de um caminho alternativo àquele da superfície, que os espíritos percorrem com suas canoas de metal.

** Os versos apresentam uma metáfora para o deslocamento do vaká pelo fundo do rio. Ele vai passando de lugar em lugar até chegar nas cabeceiras, assim como os blocos duros de argila dura da terra firme (mapotko), que forma uma escada nos barrancos. Ora, mas os próprios blocos são ditos através de suas metáforas especiais 'de surgimento' (anõ shovima): Ene Voã, os espíritos demiurgos do mundoágua, fizeram pedaços de argila com cabeças de antas-frio (isto é, da referência-frio).

*** Os que ensinaram meu vaká a cantar, o tio e seus parentes. O termo mane se refere, mais especificamente, às melodias dos cantos.

**** Isto é, a língua dos marubo, dos viventes

***** A mim, Pedro, o corpo-carcaça.

Está claro que o poema tem um contexto concreto: "meu corpo-carcaça" aponta diretamente ao corpo de Pedro Cesarino em relação a seu vaká, que assume a voz do canto. Essa característica

uma intencionalidade análoga à humana, funcionam como hipóstases das espécies animais a que estão associados, criando um campo intersubjetivo humano-animal mesmo ali onde os animais empíricos não são espiritualizados” (2002: 354). 
é intransponível e diz muito da poética de um iniki, que não é feito para ser reiterado indefinidamente como uma canção popular que almeja alguma ideia ocidental de eternidade. Há ainda outro problema para a tradução reiterável: o mundo da modalizações referenciais, como o "vento-rio", as "antas-frio" etc., é praticamente incompreensível para um brasileiro médio, mesmo que interessando por poesia e antropologia, porque organiza um cosmo marubo, em que a categorização referencial "-rio" não equivale plenamente a um "rio" determinado, ao mesmo tempo em que não exclui o mundo concreto em que vivemos. Uma tradução dessa concretude do iniki de Iskõ Tae é parte intrínseca do que se pode cantar; em certo sentido, a tradução passa a ser mesmo dar à voz Iskõ Tae num momento gravado, desenho-traço de gravador e papel. É também o inevitável cruzamento de vozes de Iskõ Tae, Armando Cherõpapa Txano, Pedro Cesarino e minha, que arranjo e remanejo mais do que arrumo, ao modo de um xamã para Cunha (2009: 107), ao mesmo tempo em que inevitavelmente devo inserir a minha própria voz e corpo; talvez por isso eu só possa também adotar "uma linguagem que expressa um ponto de vista parcial" (ibid.: 108), ainda que esse ponto de vista possa ser (e até deva ser) metamórfico, para tecer relações mais íntimas entre as descontinuidades, mas num processo de torções que só domino em parte e que em parte me domina quando canto. O resultado é talvez uma paralaxe que não resulta numa visão global do objeto: a cada mudança que se opera, ele próprio também se altera um pouco, dando no espaço da diferença a chance de uma ligação de pensamento.

\section{0}

Guilherme Orlandini Heurich apresenta uma nota curiosa sobre a reiterabilidade possível dos cantos xamânicos araweté, depois que são gravados. É longa, mas merece ser transcrita integralmente: 
Não posso encerrar essa introdução sem falar sobre um episódio que ficou conhecido entre os Araweté e alguns não-indígenas que trabalham com eles como o "pajé no pen-drive". O use de rádios com entradas para pen-drives se popularizou durante a minha estada entre eles e devo dizer que participei dessa popularização. Certa noite, ainda em meu primeiro período de campo com eles, Imajoro e eu conversávamos na casa em que eu estava hospedado. Ele perguntou-me, então, se os cantos que escutávamos no meu gravador poderiam ser colocados para tocar nos rádios de pilha. Buscamos em seguida um desses rádios e, com um pen-drive, colocamos o pajé para tocar. Os rádios usados pelos araweté são vendidos em abundância em Altamira, fabricados provavelmente na China, e são modificações simples de rádios antigos com deck para fita $k 7$. Modificações, isto é, inovações: não são rádios antigos modificados literalmente para comportar pen-drives, mas sim rádio novos, cujo design é similar aos antigos, exceto pela ausência do deck de fitas $K 7$ e a presença de entradas $U S B$ e de cartões de memória. Os poucos pen-drives que existiam na aldeia quando cheguei reproduziam aquilo que havia sido gravado neles na ocasião de sua compra em Altamira: melody, tecno-brega, forró e o onipresente Amado Batista. Não sei exatamente há quanto tempo existem esses rádios, mas sei apenas que, até aquele momento, a reprodução de músicas araweté ocorria através de gravadores de mão simples, os quais alguns araweté possuem. Se a reprodução não era novidade, a amplitude que os rádios tomaram nos meses seguintes foi espantosa: somente em uma aldeia, três conjuntos de rádios com pen-drive haviam se multiplicado em mais de trinta quando voltei cinco meses depois. A notícia dos rádios tocando pajé logo se espalhou e, não muito tempo depois, lembro de ser acordado na madrugada daquele mesmo verão, por alguém (que, depois fui saber, tinha vindo de outra aldeia) e gritava "Diréme, bora botar o pajé no pen-drive!". Não muito tempo depois, os Araweté pediam frequentemente aos funcionários da Funai, em Altamira, para passar cantos de um pen-drive para 
outro. Ainda que apreciassem essa movimentação, alguns dos funcionários reclamavam porque não sobrava tempo, muitas vezes, para fazer o seu trabalho na Funai. Assim, um pouco sem intenção, participei de uma popularização do "pajé no pen-drive" e da circulação de cantos araweté. Pouco tempo depois, digitalizei as fitas $K 7$ que Eduardo Viveiros de Castro gravara nos anos 1980 e leveis os MP3 para as aldeias, o que gerou uma maior circulação de pendrives e rádios. (2015: 51-52)

O que vemos aqui é a dupla relação do canto xamânico: por um lado, ele é produzido em determinado contexto, produzindo inclusive seu próprio contexto através do canto, e não cabe à reiteração; por outro, a possibilidade técnica da gravação, já entre os araweté produz um deslocamento da função para o interesse estético. Nesse sentido, já há um modelo citacional enxertado, que desloca a noção mais purista de contexto. Heurich pensa a questão em outro momento:

Parece-me que podemos pensá-las [as citações da fala alheia] como ações que sobrepõem diversos contextos (ou mundos) em uma mesma fala. Quando essa fala questiona a humanidade dos envolvidos e usa palavras cujo referente não é fixo - inimigo, tatu, gente, etc. -, creio que a definição de um 'contexto referencial' da citação fica comprometida. $\mathrm{Ou}$ seja, se 'gente' é algo que aponta para referentes (mundos) diferentes de acordo com o sujeito que fala, talvez não seja possível estabelecer um contexto de referência e, portanto, talvez não haja contexto para ser 'descontextualizado'. Por isso penso que a noção de contexto possa ser substituída pela de mundo e a ação de citação possa ser pensada como uma sobreposição de mundos. (ibid.: 150-1)

Essa sobreposição de mundos está já dentro de um suposto mesmo mundo da aldeia e se desdobra nos outros mundos que a tra- 
dução faz chocar. O pajé toca no rádio e no pen-drive, passível de repetição e tradução, torna-se objeto de um contexto sempre-diferido. $\mathrm{O}$ que isso pode implicar na hibridização de um canto traduzido para ser cantado em mundo tão diverso?

\section{1}

As gravações que Pedro me enviou alguns meses depois me pasmam: são na verdade áudios de quase uma hora, com cantos prolongados que se emendam quase inconsúteis ao ouvido destreinado, e só posso perceber o que tenho diante de mim porque recebi a devida informação dos minutos em que cada um dos dois cantos começa e termina. Sem precisão no conhecimento da língua, sem instrução nos modos da enunciação dos espíritos, a mera base ocidental de melodia e letra basicamente não é capaz de operar um trabalho crítico sobre o gesto marubo. Assim, cego da imagem perdida, surdo funcional da poética, vou guiado por Pedro entre e-mails e conversas: tateio e tento uma primeira retranscrição dos cantos, com um ouvido obcecado do áudio e um olho cravado na transcrição de Oniska. Como eu já buscava reencenar vocalmente os cantos e suas traduções, não busquei a minúcia proposta por Dennis Tedlock, em "Learning to Listen: Oral History as Poetry" (1975), para transcrições de gravações. Assim fica a nova transcrição e as duas primeiras versões dos cantos:

1.1-2 (Iskõ Tae responde ao pedido de cantar novamente para Isko Mayãpa/Pedro Cesarino, súbito)

ẽ chinã kenerao

ẽ chinã kenerao

ene kenemataki

yove kenemataki

êhé 
$\tilde{e}$ anõ oĩa

aivo kenese

chinã revõ veyamash

êhé

kenekia rakánõ

êhé

ẽ anõ vanaa

ẽ chinã kene

êhé

ẽ chinã kenenõ

teki vakĩ ikirao

eri rivi yonã

êhé

\section{1}

meu saber em desenho meu saber em desenho não é com desenho-rio nem desenho-espírito

\section{êhé}

que consigo enxergar

esse desenho está

diante do meu coração

$$
\text { êhé }
$$

desse meu desenho aí

êhé 
que farei meu cantar

saber em desenho

$$
\text { ehé }
$$

com saber em desenho

eu caminho só assim

como estou a te contar

$$
\text { êhé }
$$

\title{
1.2
}

meu saber em traço

meu saber em traço

não é com um traço-rio nem sequer com traço-além

\section{êhé}

que consigo enxergar

esse traço agora está

diante do meu coração

$$
\text { êhé }
$$

do meu traço agora aí

\author{
êhé \\ que farei meu cantar \\ saber em traço \\ ehé \\ com saber entre traço \\ eu caminho só assim \\ como estou a te contar \\ êhé \\ (pausa e início de conversa com o duplo/vaká)
}


Na primeira coluna, sublinho as alterações em relação à transcrição de Cesarino: em seu trabalho de tradução dos cantos, ele justificadamente deixa de lado o canto de refrão - construção sem sentido lexical - e as repetições. O leitor do texto transcrito também não pode perceber que, para além do fato de que muitos versos têm sete sílabas em marubo, toda a performance é organizada em sete sílabas cantadas, seja pela elisão/supressão de sílabas sobressalentes, seja pelo desdobramento de uma mesma vogal em mais sílabas entoadas: há aí uma organização métrica que deixa rastro no texto transcrito, mas se realiza plenamente apenas na voz. Ela se organiza assim até mesmo no refrão assêmico: o que grafo como êhé na verdade algo como "ê-he-he-he-he-he-he", que por sua vez aceita variações melódicas e rítmicas menores e também timbrísticas ou mesmo de ordem vocálica. Com a presença do refrão, percebo as modulações sêmicas do canto a partir de uma respiração vocal, ao mesmo tempo, compreendo as repetições como modelos de ênfase e gesto: não é só um aumento de tensão, mas a própria construção do espaço em que o canto se dá.

Tento então traduzir o canto em seu modelo de sete sílabas, com variações, respeitando ao mesmo tempo as repetições e os refrões como modos poético-organizacionais fundamentais. A palavra kene e seus derivados se repete oito vezes ao longo dos trezes versos deste canto curto; por isso mantenho uma repetição com "desenho". Depois, incomodado com a repetição da palavra (demasiado sonora neste canto em português), graças a conversas com Pedro, tomo coragem de largar o termo escolhido por ele para traduzir kene, que não designa desenhos miméticos (mas sim grafismos, muitas vezes geométricos), nem apenas imagens visíveis, mas também os desenhos invisíveis que o xamã consegue perceber, segundo Els Lagrou (53-4). Além disso, kene é um desenho que se opõe a outros modos de desenhar. Como afirma Lagrou em outro momento, acerca dos Kaxinawa:

No discurso kaxinawa sobre a percepção e produção visual, yuxin e dami são usados para referir-se à imagem ou 
figura, conceitos opostos ao abstrato e geométrico kene. Os Kaxinawa separam primeiramente, o fenômeno do kene de outras imagens percebidas ou produzidas para depois associá-lo à escrita (o kene dos estrangeiros). (115)

Além disso, para ela "Kene parece estar ligado à linguagem e, através da linguagem, ao conhecimento e ao poder." (ibid: 120). ${ }^{11}$ Seu estudo não é precisamente sobre os Marubo, mas me parece pertinente para a questão; por isso, optei por "traço", como um movimento de inscrição no corpo e na imagem, mas também como uma espécie de rastro residual que me aparece como poema em gravação e papel.

Outro problema que surge, ao traduzir os dois cantos, é a repetição de yove, que Cesarino traduz como "espírito", mas anota também como "espíritos ou "entidades prototípicas" (414). Em nota a yove- $a$, que ele traduz como "espiritizar", assim justifica: "Espiritizar" pretende traduzir yove-a (espírito + verbalizador), isto é, o processo de tornar-se outro, de adquirir características "hiper" ou "extra" humanas que implicam na transformação do corpo (e do duplo, vaká) e na progressiva entrada nas redes do parentesco sociocósmico. Não se trata, portanto, de "espiritualiza-

${ }^{11}$ Em outro livro, Lagrou descreve um ritual kaxinawa em que vemos claramente o vínculo entre o хипи kene e o canto, pois ambos constróem o corpo (2009:456): "Primeira mente, durante o rito de passagem, um banco é esculpido, pelos pais, das raízes tubulares da samaúma à imagem da criança: 'duas pernas com um buraco no meio', como diz o canto. Vida é insuflada no banco através de um canto ritual e um banho no rio, onde os homens ringem o banco de vermelho, levando-o para casa onde as mães o pintam com o хипи kene, o motivo da samaúma. [...] $\mathrm{O}$ canto se dirige ao banco como a uma criança, para que passe suas qualidades para a criança: a vida longa de uma samaúma com raízes firmemente plantadas ('que não anda por todo canto'), um 'coração forte', que não sente medo à toa, e um conhecimento sobre os segredos da vida e da morte atribuídos em mito a essa árvore. $\mathrm{O}$ banco usado pelas crianças para descansar durante as intervenções rituais, é produzido pelas mesmas técnicas que produziram a estrutura da criança no ventre e recebe a mesma decoração que receberá a pele da criança depois do rito de passagem." 
ção", isto é, de alguma espécie de evolução espiritual em direção a um princípio divino unívoco, de elevação do material ao imaterial característica de diversas traduções religiosas. (196, n. 3)

Carolina Villada Castro anota sobre o termo que ele foi traduzido ao espanhol como otro:

\begin{abstract}
Minha escolha tem a ver com a alteridade cosmopolítica com que agem os yove através dos cantos, a saber, os outros (duplos mortos, animais, vegetais e suas simbioses) que ouve e canta o xamã. Igualmente, yove aponta um 'deviroutro' permanente do xamã, isto é, seu exercício de iniciação permanente no meio do canto, esse sair de si ou passagem à exterioridade de si, qual se repete no decorrer do canto como condição básica para a escuta dos povos alheios. (58)
\end{abstract}

O que Castro quer com isso é reiterar o que ela vê como "alteridade cosmopolítica" dos Marubo. Mudando de grupo, Orlando Calheiros comenta sobre o termo -a'uwa entre os Aikewara: "todo awa esconde em si mesmo uma díade, cada um é, na verdade, dois: é, simultaneamente, ele mesmo, uma pele-invólucro, e seu 'outro-mesmo', seu 'companheiro' (irutehé'hyga), um duplo (-a’uwa) que vive em sua barriga" (90). Na verdade, é ainda um pouco mais complexo, pois "No idioma local, se diz que essa imagem é - $a$ 'uwa, coisa totalmente diversa de uma imagem, seria como uma 'alma', uma 'imagem-diferente', uma 'imagens-espírito', um duplo" (ibid: 55). Em nota na mesma página, ele ainda percebe o problema tradutório como um todo:

-A'uwa é um daqueles conceitos que a tradução antropológica, inspirada pela reflexão de Vernant (1965) acerca do kolossós grego, optou por abrigar sob a mancha semântica do termo duplo (cf. Carneiro da Cunha 1978 e Viveiros de Castro 1986), que engloba, por exemplo, tanto o me-karõ/karon/garon dos povos jê (Carneiro da 
Cunha op.cit, Coelho de Souza 2002), como o vaká dos Marubo (Cesarino 2011).

A solução de Calheiros é muitas vezes verter por "outro-mesmo", o que funciona como tradução para o vaká marubo, mas que também parece se aproximar da ideia de "espíritos" dada por yove. Enfim, o problema tradutório se multiplica com os equívocos possíveis. Desse modo, tentando conjugar as ideias de Cesarino, de Castro via traduções espanholas e de Calheiros em outras línguas, também por julgar o termo "espírito" muito longo e poeticamente incômodo e vocalmente excessivo, ousei arriscar uma primeira chance de verter yove, em seu modo referencial, como "além", de modo que yove kenemataki ficou como "nem sequer com traço -além". Além" aqui como deslocamento de espaços de relações, ou seja, como referencial daquilo que não está apenas no aqui-agora da vivência humana, sejam os espíritos, duplos e mortos, ou a alteridade animal e vegetal em jogo. Tenho plena ciência do equívoco possível com a noção de além ocidental, mas aposto nesse equívoco como lugar do pensamento e como um modo - arriscado, por que não? - de ligar pensamentos. Dois desvios de percurso, ou torções - como prefiro chamá-las a partir de Levi-Strauss - num desdobramento de escutas que tenta cruzar o ouvido poético ocidental com a demanda ética que o canto me lança. São esboços.

\section{2}

Também organizei uma nova transcrição do iniki mais longo, seguida de duas traduções:

2. (Conjunto de cantos polifônicos e simultâneos de cura skõki, começa o canto de Iskõ Tae)

êhê 
Vari Waka wera

we reto iniai

ene koĩ wichnãrao

retorave iniai

êhê

(pausa, sopros, tosses)

ene mai keneno

ene mavã shokoa

machit awainiai

êhê

ene vai teasho

ene txoa rakáa

watxo itãe kaniaivõ

machit ati awema

ikivomã ikitõ

ene txoa rakáa

machit awainiai

áve ea paríki

ene matso wetsãnõ

ene matso wetsãnõ

matsi awá voshká

veõini otivo

matsi awá voshkapá

teki ina iki

êhe

tsoa mané vítima

tsoa mané vítima

ea veso ayavõ

noa mawa vana

vanakavi yosisho

eri rivi yonã 
êhê

ẽ yora shakárao

nea mai shavayash

matõ vana tanai

awẽ aki amainõ

ẽ rome kokavõ

ẽ rome kokavõ

yove rewe kenenõ

vana mekiarao

ato vana yosii

mãta ẽ akai

(levanta da rede)

ẽ chinã kenerao

ẽ anõ oĩya

aivo kenese

chinã revõ veyamash

yove kene vetsãi

yove kenematai

\section{êhê}

vari waka wera

we retó iniai

ene koĩ wichnara

reto rave iniai

\section{êhê}

(pausa, tosse)

awesa oĩ

oĩra ikia

nori rivi oĩno 
ẽ rome kokavo

ato anõ tsekaa

tseka yosisho

eri rivi anõsho

iki anõ ána

êhê

(pausa, sopros, tosses)

ẽ rome kokavo

ari rivi vanai

êhê

(emenda o canto em um shõki para curar um doente mantendo a melodia)

2.1 (Conjunto de cantos polifônicos e simultâneos de cura skõki, começa o canto de Iskõ Tae)

êhê

vento deste rio-sol

contra o vento eu vou

névoa lá da nuvem-rio

contra a névoa agora vou

êhê

(pausa, sopros, tosses)

eu pulando agora vou

'spinho-rio a se fincar

no desenho em terra-rio ("ene mai keneno") 


\section{êhê}

raia-rio colossal

que fechou a via-rio

a pessoa moça assim

não consegue mais pular

isso dizem por aí

mas pulando agora vou

raia-rio colossal

sou assim e sempre fui

noutro morro desse rio

noutro morro desse rio

colocaram tempo atrás

as argilas de anta-frio

sobem sobem sem parar

as argilas de anta-frio

êhê

os que ensinam a cantar

os que ensinam a cantar

fazem minha proteção

sua fala eu aprendi

falas lá do sabiá

como estou a te contar

êhê

meu corpo-carcaça aí

na morada de vocês

imitou a fala bem

nesse tempo sucedeu

que os meus tios-espírito

que os meus tios-espírito

com desenho de rapé ("yove rewe kenenõ")

arrumaram o falar 
e ensinaram fala ao tal

mas eu bem entendi

(levanta da rede)

no desenho do pensar

que eu uso para ver

o desenho que se fez

diante do meu coração

qual desenho-espírito

não-desenho-espírito

êhê

vento deste rio-sol

contra o vento eu vou

névoa lá da nuvem-rio

contra a névoa agora vou

êhê

(pausa, tosse)

mas então o que será

que eu ali encontrarei?

juntos vamos descobrir

os meus tios-espírito

aprenderam a extrair

extrair a qualquer mal

assim fazem pra que eu

faça tudo assim também

êhê

(pausa, sopros, tosses) 
os meus tios-espírito

me falaram bem assim

êhê

(emenda o canto em um shõki pra curar um doente mantendo a melodia)

2.2 (Conjunto de cantos polifônicos e simultâneos de cura skõki, começa o canto de Iskõ Tae)

êhê

vento deste rio-sol

contra o vento eu vou

névoa lá da nuvem-rio

contra a névoa agora vou

$$
\hat{e} h \hat{e}-\hat{e} h \hat{e}-\hat{e} h \hat{e}
$$

eu pulando agora vou

'spinho-rio a se fincar

\section{nos traços da terra-rio}

\section{êhê}

raia-rio colossal

que fechou a via-rio

a pessoa moça assim

não consegue mais pular

isso dizem por aí

mas pulando agora vou

raia-rio colossal

sou assim e sempre fui

noutro morro desse rio

noutro morro desse rio

colocaram tempo atrás 
as argilas de anta-frio sobem sobem sem parar as argilas de anta-frio

$$
\hat{e} h \hat{e}-\hat{e} h \hat{e}
$$

os que ensinam a cantar os que ensinam a cantar fazem minha proteção sua fala eu aprendi falas lá do sabiá como estou a te contar

$$
\text { êhê - êhê }
$$

meu corpo-carcaça aí na morada de vocês imitou a fala bem nesse tempo sucedeu que os meus tios-espírito que os meus tios-espírito com traçar de voz-além arrumaram o falar e ensinaram fala ao tal

mas eu bem entendi

$$
\text { êhê }
$$

pelo traço do pensar que eu uso para ver eis o traço que se fez diante do meu coração era igual um traço-além desigual do traço-além

$$
\text { êhê }
$$


vento deste rio-sol

contra o vento eu vou

névoa lá da nuvem-rio

contra a névoa agora vou

$$
\hat{e} h \hat{e}-\hat{e} h \hat{e}
$$

mas então o que será

que eu ali encontrarei?

juntos vamos descobrir

os meus tios-espírito aprenderam a extrair extrair a qualquer mal assim fazem pra que eu faça tudo assim também

$$
\hat{e} h \hat{e}-\hat{e} h \hat{e}-\hat{e} h \hat{e}
$$

os meus tios-espírito

me falaram bem assim

\section{êhê}

(emenda o canto em um shõki para curar um doente mantend a melodia)

Também esboços, sublinho igualmente os acréscimos que faço para a performance de Iskõ Tae/Armando Cherõpapa Txano (repare-se que cada unidade de êhé equivale a uma unidade métrica inteira de sete sílabas cantáveis), bem como escólios do que acontece durante o canto, seus ruídos de tosse, suas pausas, sua saída da rede (indicação dada por Pedro), tudo isso um pouco ao modo da proposta de tradução para o canto "Emplumando a grande castanheira” de Kãñïpaye-ro, feita por Álvaro Faleiros (2019) a partir das anotações de Eduardo Viveiros de Castro (1986) e em diálogo tensionado e crítico com a tradução poética de Antônio Risério 
(1993). A minha transcrição performance do canto mais longo se dá sobre outras vozes simultâneas, recusa qualquer ideia de pureza que o ouvido ocidental acumulou pelas gravações de estúdio. Mas devo dizer que essa transcrição precisa ser assim porque não se encontra no contexto de Oniska, em que uma série de questões cosmopoéticas vão sendo tecidas minuciosamente pelo estudo etnográfico de Cesarino. A minha transcrição é uma pré-partitura de reperformance, e não um projeto de apresentação ao leitor interessado. $\mathrm{O}$ mesmo acontece com as traduções, que permanecerão como partitura-em-esboço. Em negrito, como no primeiro canto, estão as minhas próprias variantes da primeira para a segunda tradução; o que fica em negrito são questões que levei diretamente a Pedro, para consultar se ali eu passava do limite hermenêutico. Essas versões, como um todo, também foram enviadas a ele como um primeiro teste, junto com dois esboços de cantos, que gravei pelo celular. A voz aqui também passou a ser um esboço interminado.

\section{3}

Enquanto eu cantava publicamente pela primeira vez o segundo iniki, em Paraty, em julho de 2019, quase três anos depois do início deste percurso - dentro da pequena casa Oka Babel, que havia criado uma fala-performance de poéticas ameríndias e antigas a ser realizada comigo, Luciane Alves e Iván García López - , um grupo de apoiadores de Bolsonaro atravessou a rua à frente da porta, fazendo um barulho intenso; diante disso, hesitante nesta voz-esboço em que eu cantava, percebi que inconscientemente apenas aumentei o volume vocal, em vez de pausar o canto e retomar no retorno do silêncio. Cantei ao som do chocalho tocado por Luciane, como se o canto me levasse, fosse eu um rádio-ouvinte, um rádio-transmissor, rádio-comunicador, ou mero walkie-talkie do canto que, cantando, eu escutava cada vez mais forte em mim. Depois, cantamos eu e Luciane "Mehcinut", enquanto Iván lia minha tradução em seu português de sotaque mexicano, dando mais uma voz e camada ao 
processo. Sei que ao fim de tudo, eu me encontrava em um estado alterado da mente que me assombrou e fascinou ao mesmo tempo: sentia que tinha cantado cantos de outros, que fora a voz de um outro (Iskõ Tae? Tekãpapa? Pedro? um anônimo? outro vaká, talvez um meu irmão mais velho? uma produção do inconsciente?), e ao fim caía fora de mim, extático de um entusiasmo. Foi muito tempo até o retorno.

$\mathrm{Na}$ verdade, tem sido assim a cada vez que recanto este iniki, sobretudo se vinculado de algum modo a "Mehcinut". Lembro que Eliade anotava, a respeito de xamãs da América do Norte, que "o que distingue um xamã de um outro indivíduo do clã não é a posse de um poder ou de um espírito guardião, mas a experiência extática” (1983: 99). É isto que experimento aqui? Percebo que algo nestes cantos não me concede o pleno canto, nem se aceita no modelo da reiterabilidade: há um saber que preciso ganhar com eles, e por ora só tenho os próprios cantos como caminho do saber: eles são meio e meta a um só tempo.

\section{4}

Numa entrevista, Eduardo Viveiros de Castro faz a famosa analogia entre o encontro do índio com a onça sobrenatural que fala na floresta e o encontro do civil com uma batida policial:

Quem responde à interpelação de um agente não humano, aceita que ele é humano, e, nesse processo, corre o risco de perder a própria humanidade, porque entre dois sujeitos de espécies (em sentido lato) distintas, o que há de comum é o que os separa. Esse é o problema colocado pelo perspectivismo. Tudo é gente, mas tudo não pode ser gente ao mesmo tempo, uns para os outros. Quando dois seres, duas espécies diferentes, entram em contato, constata-se a presença de uma tensão constante, latente ou patente, em torno da posição de sujeito, um combate pelo ponto de vista. De 
quem é o ponto de vista? Esse mundo é o mundo de quem? Trata-se de um combate que se pode perder. Você pode por várias razões ser enganado, passado para trás - um estelionato fenomenológico. De repente, você se dá conta de que aceitou a definição de realidade que o outro propõe. E, nessa definição, você não é gente; quem é gente é o outro. Ouvindo essas histórias de índio, tão comuns na experiência do etnógrafo, fiquei com a nítida impressão de que se tratava de algo da mesma ordem que o aperto que você passa quando é parado pela polícia, como se diz, e 'ela' pede seus documentos. Sobretudo para aquele que não tem parente - alguém pobre, isto é, que não tem parente influente, cujo único 'parente' é o Estado, essa é uma experiência totalmente aterradora, porque ele sabe que tudo pode acontecer. O sujeito pode terminar torturado e morto em uma delegacia de periferia, e nunca mais o encontram. 'Quem é você?' - a polícia pergunta. 'Mostre os seus documentos'. Todo mundo tem medo, mesmo quem é inocente. Porque, entre aspas, ninguém é inocente; perante o Estado, todos têm contas a prestar. $[\ldots]$

Situação complexa. Em geral você volta para casa meio tonto, porque um encontro com a polícia é igual a um encontro com a onça no mato. O teu ponto de vista foi colocado em questão. Você não sabe com quem está falando. Mais uma vez a mesma questão: 'Com quem você está falando?' 'Quem sou eu?' 'Cadê teus documentos?' Não se trata aí de um caso particular. (233-234)

É uma analogia talvez demasiado equivocada, porém fértil em seu equívoco, talvez um dos momentos em que Viveiros de Castro leva mais longe sua proposta da equivocação. Pergunto-me, se ao contracantar para o grupo bolsonarista, eu não estava ali disputando o ponto de vista, decidindo o lugar da onça pelo volume da voz. Nesse momento específico, sei que os vi primeiro. Não sei na próxima. 


\section{5}

A única honestidade que me cabe num estudo sobre uma performance a caminho e inacabada é entregar seu estágio inacabado como parte constitutiva, como um já acabado paradoxalmente em movimento. Em conversas com Álvaro e Pedro, em diálogos com as performances multilíngues que venho realizando com a Pecora Loca, fiz ainda mais uma partitura da performance, com novas alterações tradutórias que agora não marco, dessa vez incorporando versos formulaicos da poética marubo e também as repetições como possibilidades de bilinguismo da voz (é o que se deve entender com os textos paralelos escritos em marubo). Na verdade, tenho diante de mim uma partitura aberta, com variantes para cantar em português e marubo, segundo decido em cada caso, levando em conta possibilidade de ampliar repetições, em qualquer língua, instaurar novas repetições, produzir silêncios, reentoar os refrões etc. Entendo que essa abertura que me concedo é o limite também de dupla torção que preciso (me) dar ao canto como modo de relação: a imitação melódica não pode ser mero decalque, assim como o tempo, os ruídos, as ênfases. Se o canto de Iskõ Tae na voz de Tekãpapa foi feito apenas uma vez e tornado reiterável na gravação de Pedro e na tradução de Pedro como Cesarino, estas notas tradutórias precisam sair da mimese plena para um movimento que ao mesmo tempo desdobre e preserve, que deixe os cantos lá perto dos marubo, sem que nos impeça de política, ética, poeticamente cantá-los em português. É uma iniciação, com certeza, e não sei se ela terá propriamente um fim.

\section{6}

Recentemente, Luciane Alves me disse que não se lembra de ter sido um grupo de bolsonaristas a atravessar a rua com ruídos, enquanto em cantava o canto de Iskõ Tae, mas que eu em meu transe teria (con)fundido um grupo dos Guarani de Paraty com os bolsonaristas, que corriam pela cidade e interromperam no mesmo dia as 
falas públicas de Glenn Greenwald a não muitos metros dali, já que eu estava, de algum modo, endeusado em meu entusiasmo. Estou confiante-hesitante no traço dessa lembrança; ao confrontá-la um pouco mais, questionando seu relato, ela também hesitou sobre o que guardava consigo: talvez nenhum de nós saiba qual das duas lembranças confirme o lugar do fato, porque o que vara o corpo é também difuso em seu rastro. Não se sabe com quem estávamos falando, nem que lugar ocupamos naquele momento. Como um dedão latejante atravessa como memória a lembrança de um encontro fortuito e fértil, e não pode ser plenamente desvinculado dessa sorte do encontro, lembro claramente aquilo que não mais confirmo. Faz parte do que se guarda de uma performance.

\section{7}

Dois cantos de Iskõ Tae, vaká-duplo de Pedro Cesarino, a partir da voz de Armando Cherõpapa Txano, via transcrição e tradução e Pedro Cesarino

1.

(Iskõ Tae responde ao pedido de cantar de novo a Isko Mayãpal Pedro Cesarino, súbito)

esse traço do pensar esse traço do pensar não é com um traço-rio ẽ chinã kenerao nem é com um traço-além

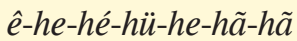

que consigo enxergar esse traço agora está dentro do meu coração

chinã revõ veyamash 
e-he-hü-he-hü-he-he...

do meu traço agora aí

$$
\text { ê-he-hé-hü-he-hã-hã }
$$

que farei meu cantar traço do pensar

\section{ê-he-hé-hü-he-hã-hã}

com o traço do pensar

eu caminho só assim

como estou a te contar

eri rivi yonã

ê-he-hü-he-hü-he-he...

(Pausa e início de conversa com o duplo-vaká.)

$\S$

2.

(Conjunto de cantos polifônicos e simultâneos de cura skõki, começa o canto de Iskõ Tae.)

\section{ê-he-hé-hü-he-hã-hã}

vento vento rio-sol

contra o vento eu vou

névoa névoa nuvem-rio

contra a névoa agora vou

ê-he-hé-hü-he-hã-hã

ê-he-hü-he-hü-he-he

ê-he-hé-hü-he-hã-hã 
eu pulando agora vou

'spinho-rio a se fincar

no traço da terra-rio

ê-he-hü-he-hü-he-he...

raia-rio escomunal

que fechou a via-rio

a pessoa moça assim

não consegue mais pular

isso dizem por aí

mas pulando agora vou

raia-rio escomunal

sou assim e sempre fui

noutro morro desse rio

noutro morro desse rio

ene matô wetsãnõ

colocaram tempo atrás

as argilas de anta-frio

sobem sobem sem parar

as argilas de anta-frio

ê-he-hé-hü-he-hã-hã

e-he-hü-he-hü-he-he...

matsi awá voshkapá

teki ina iki

os que ensinam a cantar

os que ensinam a cantar

tsoa mané vitima

$\hat{e}-h e-h u ̈-h e-h u ̈-h e-h e$
$\hat{e}-h e-h e ́-h u ̈-h e-h a-h \tilde{a}$

fazem minha proteção

sua fala eu aprendi

falas lá do sabiá

como estou a te contar

eri rivi yonã

ê-he-hé-hü-he-hã-hã

ê-he-hü-he-hü-he-he... 
meu corpo-carcaça aí na morada de vocês imitou a fala bem nesse tempo sucedeu que os meus tios-espírito que os meus tios-espírito ẽ rome kokavõ com traço de voz-além arrumaram o falar e ensinaram fala ao tal mas eu bem entendi

\section{ê-he-hé-hü-he-hã-hã}

esse traço do pensar esse traço do pensar é que eu uso para ver eis o traço que se fez dentro do meu coração é chinã kenerao era igual um traço-além chinã revõ veyamash desigual do traço-além

\section{ê-he-hé-hü-he-hã-hã}

vento vento rio-sol contra o vento eu vou névoa névoa nuvem-rio contra a névoa agora vou

\section{e-he-hü-he-hü-he-he \\ ê-he-hé-hü-he-hã-hã}

Vari Waka wera we retó iniai ene koĩ wichnara reto rave iniai

mas então o que será que eu ali encontrarei? juntos vamos descobrir os meus tios-espírito aprenderam a expurgar 
expurgar a qualquer mal assim fazem pra que eu faça tudo assim também

\section{ê-he-hé-hü-he-hã-hã \\ ê-he-hü-he-hü-he-he \\ ê-he-hé-hü-he-hã-hã}

os meus tios-espírito

me falaram bem assim

\section{ê-he-hü-he-hü-he-he}

(Emenda o canto em um shõki para curar um doente, mantendo a melodia.)

\section{8}

Ressinto-me de algum modo porque o iniki de Iskõ Tae prossegue emendado ao shõki curativo, sem qualquer ruptura gritante, ao passo que o canto que assumo e me toma deve terminar sempre conforme uma partitura, por mais que esteja aberta. Entretanto, ainda lembrando a primeira apresentação, em Paraty, fizemos o segundo canto de Iskõ Tae e em seguida "Mehcinut" wolastoqiyik com o poema de Whitman; naquele momento, Luciane saiu cantando e andando entre as pessoas que nos assistiam, quebrando assim a nossa programação prévia e, talvez aberta e ligada pelo iniki marubo, por sua vez abrindo e ligando outros pontos: saímos dali certamente movidos. Seria possível falar de cura, mesmo na ausência de uma doença clara? Há por certo um cuidado, uma marca. Algo se desdobra, ou liga pensamentos, como um cruzamento de um rio que não conheço bem e me assusta, no próximo canto que deve ser cantado; também ele, como eu e os outros que ali ouvem, sairá alterado. 


\section{Referências}

Brandão, Jacyntho Lins. "O entusiasmo poético" In: Muniz, Fernando (org.) As artes do entusiasmo. Rio de Janeiro: 7letras, 2011, p. 21-35.

Calheiros, Orlando. Aikewara: esboços de uma sociocosmologia tupi-guarani. (Doutorado em Antropologia). Museu Nacional, da Universidade Federal do Rio de Janeiro, Rio de Janeiro, 2014.

Castro, Carolina Villada. O proliferar dos outros: tradução e xamanismo. (Mestrado em Estudos da Tradução). Universidade Federal de Santa Catarina, 2017.

Cesarino, Pedro de Niemeyer. Oniska: poética do xamanismo na Amazônia. São Paulo: Perspectiva, 2011.

Cesarino, Pedro de Niemeyer (org.). Quando a terra deixou de falar: cantos da mitologia marubo. Org. trad. e notas de Pedro de Niemeyer Cesarino; a partir dos cantos de Armando Mariano Marubo, Antonio Brasil Marubo, Paulino Joaquim Marubo, Lauro Brasil Marubo e Robson Dionísio Doles Marubo. São Paulo: Editora 34, 2013.

Cunha, Manuela Carneiro da. "Xamanismo e tradução: pontos de vista sobre a floresta amazônica” Cultura com aspas, São Paulo: Cosac Naify, 2009. [1998]

Eliade, Mircea. Le chamanisme et le techniques archaïques de l'extase. Paris: Payot, 1983.

Faleiros, Álvaro. Traduções canibais: uma poética xamânica do traduzir. Florianópolis: Cultura e Barbárie, 2019.

Goldmand, Irving. Cubeo Hehénewa Religious thought: metaphysics of a Northwestern Amazonian People. ed. by Peter Wilson. New York: Columbia University Press, 2004. 
Heurich, Guilherme Orlandini. Música, morte e esquecimento na arte verbal Araweté. (Doutorado em Antropologia). Museu Nacional, da Universidade Federal do Rio de Janeiro, Rio de Janeiro, 2015.

Kopenawa, Davi; Albert, Bruce. A queda do céu: palavras de um xamã yanomami. Trad. Beatriz Perrone-Moisés. São Paulo: Companhia das Letras, 2015.

Lagrou, Els. A fluidez da forma: arte, alteridade e agência em uma sociedade amazônica (Kaxinawa, Acre). Rio de Janeiro: UFRJ/Topbooks, 2007.

Lagrou, Els. Arte indígena no Brasil: agência, alteridade e relação. Orientações pedagógicas de Lucia Gouvêa Pimentel e William Resende Quintal. Belo Horizonte: C/ Arte, 2009.

Malinowski, Bronislaw. "The Meaning of Meaningless Words and the Coefficient of Weirdness". In: Malinowski, Bronislaw. Coral gardens and their magic. London: Unwin Borthers, 1935.

Nodari, Alexandre. "Lugar da escuta". Disponível em https://subspeciealteritatis. wordpress.com/2018/11/10/lugar-da-escuta-alexandre-nodari/.

Pissolato, Elizabeth. A duração da pessoa: mobilidade, parentesco e xamanismo mbya (guarani). São Paulo/Rio de Janeiro: Unesp/ISA/NuTI, 2007.

Risério, Antônio. Textos e tribos. Rio de Janeiro: Imago, 1993.

Rothenberg, Jerome. Etnopoesia do milênio. Org. Sergio Cohn. Trad. Luci Collin. Rio de Janeiro: Azougue, 2006.

Seeger, Anthony. Por que cantam os Kฤsêdjê? Uma antropologia musical de um povo amazônico. trad. Guilherme Werlang. São Paulo: Cosac Naify, 2015.

Seeger, Anthony; Da Mata, Roberto; Viveiros de Castro, Eduardo. (1979). "A construção da pessoa nas sociedades indígenas brasileiras" In: Pacheco de Oliveira Filho, J. (Org.) Sociedades indígenas e indigenismo. Rio de Janeiro: Pacheco de Oliveira Filho, 1987, p. 11-29. 
Tedlock, Dennis. "Learning to Listen: Oral History as Poetry." Boundary 2.Vol. 3, No. 3, The Oral Impulse in Contemporary American Poetry, 1975, p. 707-728.

Townsley, Graham. "Song paths: the ways and means of Yaminahua shamanic knowledge". In: Townsley, Graham. L'Homme, tomo 33, n ${ }^{\circ}$ 26-128. La remontée de l'Amazone. 1993, p. 449-468.

Villas Bôas, Orlando. A arte dos pajés: impressões sobre o universo espiritual do índio xinguano. São Paulo: Globo, 2000.

Viveiros de Castro, Eduardo. Araweté: os deuses canibais. Rio de Janeiro: Zahar/ Anpocs, 1986

Viveiros de Castro, Eduardo. A inconstância da alma selvagem. São Paulo: Cosac \& Naify, 2002.

Viveiros de Castro, Eduardo. Encontros. Organização de Renato Sztutman. Rio de Janeiro: Azougue, 2009.

Recebido em: 25/09/2019

Aceito em: 20/10/2019

Publicado em dezembro de 2019

Guilherme Gontijo Flores. E-mail: ggontijof@gmail.com

ORCID:https://orcid.org/0000-0003-0081-6512. 